\title{
Evaluation of the Sound Emissions and Climate Acoustic in Proximity of One Railway Station
}

\author{
G. Cannistraro ${ }^{1 *}$, A. Cannistraro ${ }^{3}$ and M. Cannistraro ${ }^{2}$ \\ ${ }^{* 1}$ Department of Engineering of Messina, University of Messina, Contrada di Dio, 98166 Messina, \\ Italy \\ ${ }^{2}$ Research Fellow University of Ferrara, Italy \\ ${ }^{3}$ Freelancer Engineer
}

Email: gcannistraro@unime.it

\begin{abstract}
In Europe, the acceptance of the railways as a driving force for the development economic and ecological it is subject at the rail noise reduction, aspect important for people's health and the environment. The acceptance of the noise for the citizens, living in the vicinity of railway lines, is of vital importance in view of the increasing number of trains and consequently of the noise they produce. Therefore, measures to reduce the noise levels are essential to prevent health risks in the citizens exposed. Health effects due to prolonged exposure to environmental noise, rarely can cause directly damage to hearing (hearing loss). Many damages psychosomatic, can affect the apparatus: digestive, respiratory, visual, reproductive, skin and circulatory systems and blood. Precisely for these reasons, in recent decades the actions of assessment and reduction of noise, coming from the civil engineering infrastructure, have become of paramount importance and cannot longer be neglected. The aim of this study is the evaluation of noise emission coming from a railway yard inserted in an urban context, and the acoustic environment in the surrounding area and the possible presence of sources concomitants in the railway area. The work presented here is part of a larger project aimed at developing a 3-D numerical model of the survey area, to be used for the noise-mapping of the area in the existing situation, both for the simulation of future order, resulting after the inclusion of noise abatement systems aimed at reducing noise pollution.
\end{abstract}

Keywords: Noise pollution, Monitoring railway noise, Noise mapping, Acoustic climate, Acoustics legislation.

\section{INTRODUCTION}

The framework law Oct. 26, 1995, n. 447, states that noise pollution is the introduction of outdoor environment noise in likely to cause:

- annoying or disturbing to rest and to human activities,

- danger to human health,

- deterioration of ecosystems, material goods, monuments and the indoor or outdoor environment or to interfere with the legitimate use of such environments.

Health effects due to prolonged exposure to environmental noise, rarely can cause direct hearing damage (hearing loss), they not having in most cases levels capable to cause damage to the ear $[1,9]$.

Instead they are not negligible damage of type:

- Psychosocial: that affecting mainly the transmission and understanding of the word, work performance and sleep;

- Psychosomatic, that affecting on the digestive system, respiratory, visual, reproductive, skin and hematic circulatory system.
The rules and laws force indicate the maximum sound levels that are relative to the reference times (day and night), to whom can be exposed the various receptors.

In the previous works, the authors have conducted a investigation-study on noise environment of the city of

of Messina (Italy) [10, 13].

The investigation has included a preliminary classification of the territory in six acoustically homogeneous areas according to Italian regulations on the noise.

Based on the resulting acoustic zoning, 35 sites were selected for an experimental investigation; and at these sites were made measurements of the main indices for noise $\left(\mathrm{L}_{\mathrm{eq}}\right.$, $\left.\mathrm{L}_{1}, \mathrm{~L}_{10}, \mathrm{~L}_{50}, \mathrm{~L}_{90}, \mathrm{~L}_{99}\right)$ and traffic flow and composition.

Results indicate that:

a) main roads of Messina are overloaded by traffic flow during the day and that in all sites sound levels due to road traffic exceed environmental standards by about $10 \mathrm{dBA}$;

b) environmental noise exhibits a certain degree of spatial variance resulting primarily from the peculiar geomorphological structure of the town and from the transport infrastructure; 
c) more than $25 \%$ of residents should be highly disturbed by road traffic noise.

In this work, to deepen the results was carried investigation out over the city of Messina, which includes the area of the city concerned by rail traffic.

The first part of this work concerns the noise in urban areas affected by rail traffic, acquisition, and the information on individual sources that fall within the rail yard.

The sound sources are typically represented by mechanical systems vibrating, or by fluids in regime unsteady, capable of transmitting energy to the propagating medium (usually fluid, and sometimes solid) with which they are in contact.

Precisely for these reasons, in recent decades the actions of assessment and containment of noise coming from the civil engineering infrastructure have become of paramount importance and cannot longer be ignored [14, 23].

Frequently in a railway infrastructure can be performed operations of ordinary and extraordinary maintenance on vehicles rolling.

The noise which affects this infrastructure comes mainly from the parking and the transit the trucks, which are considered in the study as linear sources.

The special trolleys used to clean the wagons and other equipment such as fans, vacuum cleaners and wastewater systems, given the small size, were treated as point sources.

Each individual source, is represented by different models in operation, can be sources of noise emission, measured according to UNI EN ISO 3744.

The second part of this work concerns the assessment of the acoustic environment; which represents the recognition of the usual conditions and the maximum permissible masses in a specific area. Such assessment has the aim of avoiding that the site can be characterized by conditions of noise, or levels of noise, incompatible with the use of the settlements themselves.

\section{NORMATIVE REFERENCES IN ITALY}

The first law passed by the Italian state in the area of noise is the DPCM 01/03/1991 "Limits of exposure to noise in residential areas and in the external environment."

Today is the "The "law 26/10/1995" is the noise pollution legislation, that indicating how to protect the environment inside and outside of the habitation:

- Are fixed the exposure limit values for residential areas, falling within into the zone pertaining to road and railway infrastructure; these are treated as fixed sound sources;

- For the transport services essential (railways, airports, highways, etc.) must be expected the reorganization plans at long-term in order to reduce the noise emission;

- To transport infrastructure does not apply the criterion of the differential limit expected.

- The DPCM 14/11/97 "Determination of the limits of sound sources", and the 12.11.96 DMA, "Application of the differential criteria for continuous cycle plants" and the 16/03/98 DMA "Techniques for detecting and measuring noise "(Annex C" methodology for measuring rail noise"), are the decrees of the Framework Law governing the limit values of noise in outdoor environments and methods of measuring noise.

- The DPR 11.18.98, no. 459 "Regulations for the implementation of Article 11 of Law 26 October 1995, no. 447 , concerning noise pollution caused by rail traffic", regulates the field of noise pollution to 'interior of a wing of relevance of 250 meters from the railway track axis.

Outside of this range, it can use the limits of acoustic zoning indicated by DPCM 14/11/97 or the values indicated of the article 6 of DCPM 01/03/91, zones A and B specified by the DM 04.02.68, no. 1444 and exclusively industrial areas:

- For infrastructure of new construction, with the design speed of more than $200 \mathrm{Km} / \mathrm{h}$, there is fixed a band to 250 meters for each side from the center line of the external binary. In this band must be respected the limits shown in Tab.1;

- For lines with the design speed of less than $200 \mathrm{Km} / \mathrm{h}$, is provided a band of respect of 250 meters, on each side from the center point of the external binary.

This band is divided into two parts: A band " $A$ " wide 100 meter, nearest to the infrastructure, and the band " $\mathrm{B}$ " of 150 meters, most distant from them.

The limits are set out in Tab.2;

DPR 30.03.04, no. 142 "Provisions for containment and prevention of noise pollution resulting from road traffic, in accordance with Article 11 of the Law of 26 October 1995 No. 447", indicates how to address the issues noise pollution caused to noise traffic.

- They set the limit values of noise emissions from road traffic, and defines ranges relevance.

In Tab. 3 are shown the limits for both the outside and the internal of the habitations, so he possible is act on receptors on the infrastructure with (double glazing, noise barriers, etc.).

Table 1. Limits Fixed for infrastructure with design speed upper and/o lower at $200 \mathrm{Km} / \mathrm{h}$

\begin{tabular}{|l|l|l|}
\hline \multirow{2}{*}{ Type receptor } & \multicolumn{2}{|l|}{ Reference times } \\
\cline { 2 - 3 } & $(\mathbf{6 . 0 0 - 2 2 . 0 0 )}$ & $(\mathbf{2 2 . 0 0 - 6 . 0 0 )}$ \\
\hline $\begin{array}{l}\text { Hospitals, nursing } \\
\text { homes and rest }\end{array}$ & 50 & 40 \\
\hline Schools & 50 & -- \\
\hline All other (Category A) & $70-65$ & $60-55$ \\
\hline All other (Category B) & 65 & 55 \\
\hline
\end{tabular}

Table 2. Limits foreseen into the receptors

\begin{tabular}{|l|l|l|}
\hline Type receptor & \multicolumn{2}{|l|}{ Reference times } \\
\hline & $(\mathbf{6 . 0 0 - 2 2 . 0 0 )}$ & $(\mathbf{2 2 . 0 0 - 6 . 0 0 )}$ \\
\hline $\begin{array}{l}\text { Hospitals, nursing } \\
\text { homes and rest }\end{array}$ & -- & 35 \\
\hline Schools & 45 & -- \\
\hline All other & -- & 40 \\
\hline
\end{tabular}


Table 3. Limits Noise emissions from the road traffic

\begin{tabular}{|c|c|c|c|c|c|c|}
\hline \multirow{2}{*}{$\begin{array}{l}\text { Road type (according } \\
\text { to the Highway Code) }\end{array}$} & \multirow{2}{*}{$\begin{array}{l}\text { Subtypes of noise } \\
\text { (according Dm } \\
06 / 11 / 01 \text { Standards } \\
\text { functions and } \\
\text { geometry. For the } \\
\text { construction of the } \\
\text { roads) }\end{array}$} & \multirow{2}{*}{$\begin{array}{l}\text { Amplitude } \\
\text { range } \\
\text { acoustic } \\
\text { relevance } \\
\text { (m) }\end{array}$} & \multicolumn{2}{|c|}{$\begin{array}{l}\text { Schools, hospitals, } \\
\text { nursing homes and rest }\end{array}$} & \multicolumn{2}{|c|}{ ther receptors } \\
\hline & & & $\begin{array}{l}\text { Day } \\
\text { dB (A) }\end{array}$ & $\begin{array}{l}\text { Night dB } \\
\text { (A) }\end{array}$ & $\begin{array}{l}\text { Day } \\
\text { dB }(A))\end{array}$ & $\begin{array}{l}\text { Night } \\
\text { dB (A) }\end{array}$ \\
\hline A - Highway & & 259 & 50 & 40 & 65 & 55 \\
\hline B - suburban main & & 250 & 50 & 40 & 65 & 55 \\
\hline \multirow{2}{*}{$\begin{array}{l}\mathrm{C}-\text { suburban } \\
\mathrm{C} \text { - secondary }\end{array}$} & $\mathrm{C} 1$ & 250 & 50 & 40 & 65 & 55 \\
\hline & $\mathrm{C} 2$ & 150 & 50 & 40 & 65 & 55 \\
\hline D - Urban scroll & & 100 & 50 & 40 & 65 & 55 \\
\hline $\begin{array}{l}\text { E - urban } \\
\text { neighborhood }\end{array}$ & & 30 & \multicolumn{4}{|c|}{$\begin{array}{l}\text { Defined by the municipalities, while respecting the values } \\
\text { shown in Table C attached to DCPM dated } 14 \text { November } \\
1997 \text { and still in compliance with the acoustic zoning of } \\
\text { urban areas, as provided for in Article } 6 \text {, paragraph 1, letter a) } \\
\text { of Law no. } 447 \text { of } 1995\end{array}$} \\
\hline
\end{tabular}

Table 4. Summary of results

\begin{tabular}{|c|c|c|c|c|c|}
\hline \multirow[t]{2}{*}{ Point Code } & \multirow{2}{*}{ Type } & \multirow{2}{*}{ Start of measurement } & \multirow{2}{*}{ Day of the week } & \multicolumn{2}{|l|}{ Leq [dBA] } \\
\hline & & & & Day $(6-22)$ & Night $(22-6)$ \\
\hline \multirow[t]{5}{*}{ RUM_R2_01 } & \multirow{5}{*}{ R2 } & $16 / 02 / 2013-00.00$ & Saturday & 58.2 & 57.0 \\
\hline & & $17 / 02 / 2013-00.00$ & Sunday & 56.8 & 56.4 \\
\hline & & $18 / 02 / 2013-00.00$ & Monday & 60.2 & 57.5 \\
\hline & & $19 / 02 / 2013-00.00$ & Tuesday & 59.4 & 57.4 \\
\hline & & $20 / 02 / 2013-00.00$ & Wednesday & 59.6 & 56.7 \\
\hline \multirow[t]{5}{*}{ RUM_R2_02 } & \multirow{5}{*}{$\mathrm{R} 2$} & 16/02/2013-00.00 & Saturday & 61.5 & 59.0 \\
\hline & & $16 / 02 / 2013-00.00$ & Sunday & 59.9 & 57.9 \\
\hline & & $16 / 02 / 2013-00.00$ & Monday & 61.5 & 60.3 \\
\hline & & $16 / 02 / 2013-00.00$ & Tuesday & 63.0 & 60.6 \\
\hline & & $16 / 02 / 2013-00.00$ & Wednesday & 62.9 & 60.8 \\
\hline \multirow[t]{5}{*}{ RUM_R2_03 } & \multirow{5}{*}{$\mathrm{R} 2$} & $16 / 02 / 2013-00.00$ & Saturday & 60.8 & 58.0 \\
\hline & & $16 / 02 / 2013-00.00$ & Sunday & 58.8 & 56.7 \\
\hline & & $16 / 02 / 2013-00.00$ & Monday & 60.6 & 59.7 \\
\hline & & $16 / 02 / 2013-00.00$ & Tuesday & 62.3 & 60.3 \\
\hline & & $16 / 02 / 2013-00.00$ & Wednesday & 62.2 & 59.9 \\
\hline
\end{tabular}

\section{MEASURE OF THE NOISE CLIMATE}

The noise evaluation of the acoustic environment is been obtained through a monitoring activity of the noise in the areas surrounding the railway yard.

This to get the load of noise coming from sources of sound emissions of the railway station, or of potential sources contemporary, so as to be able to assess if the maximum permissible turn out to be respected or not..

From detailed site surveys, thorough exams of cartography was found within the bands of relevance, the presence of others 8 use class of the sensitive receptors, namely:

- three schools;

- two health facilities;

- a day center for people with disabilities;

- an hospital;

- a socio-recreational center

The receptor is means any building (including their outdoor areas of relevance) used as a living environment, work, recreation or public, restricted natural areas, public parks and outdoor areas used for recreational and operation of the social life of the community areas building land already identified by the current general plans, directly affected by the noise from the sound sources.

They are divided into two groups:

- Receptors sensitive: ie schools, kindergartens, hospitals, nursing homes and rest, etc;

- All the others.

The noise pollution to detected on a given receptor, it is evaluated by measuring the sound pressure level, represented by the change in pressure produced by the sound phenomenon than the pressure of quiet, ie the lowest pressure audible by the human ear.

The sound pressure levels can be effectively mediated over time, with an exponential laws characterized by time constants Slow, Fast or Impulse.

The reliefs of the acoustic climate were carried out through direct surveys of the areas concerned, with the use of sound level meters standardized capable of recording the sound 
pressure level inside the railway area and in the proximity of the receptors in a qualitatively homogeneous mode.

For the receptors falling in such concomitant areas, must be respected different limits for sound depending on the type of infrastructure, the band of the relevance, and the reference times according to the DMA 29/11/2000.
For the receptors falling in such concomitant areas, must be respected different limits for sound depending on the type of infrastructure, the band of the relevance, and the reference times according to the DMA 29/11/2000.

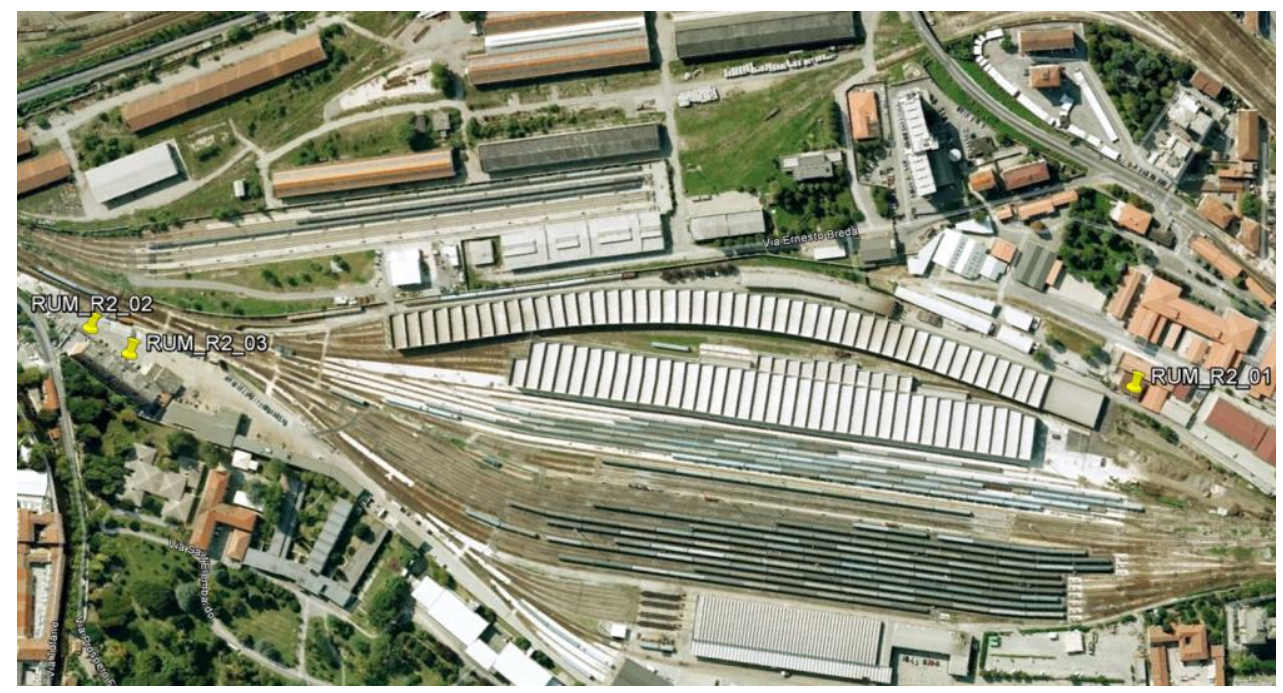

Figure 1. Identification of the measure stations of the noise

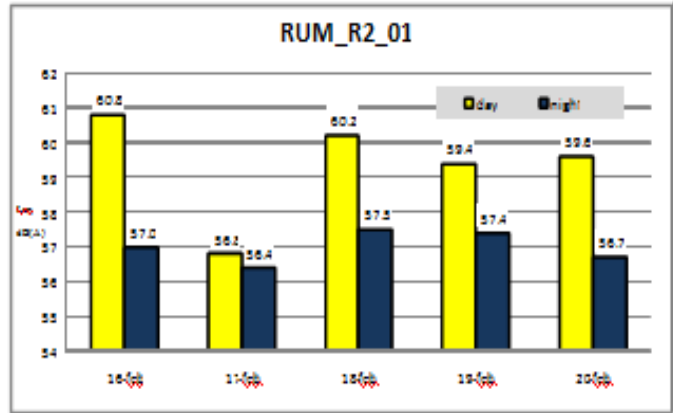

Figure 2.Weighted equivalent levels

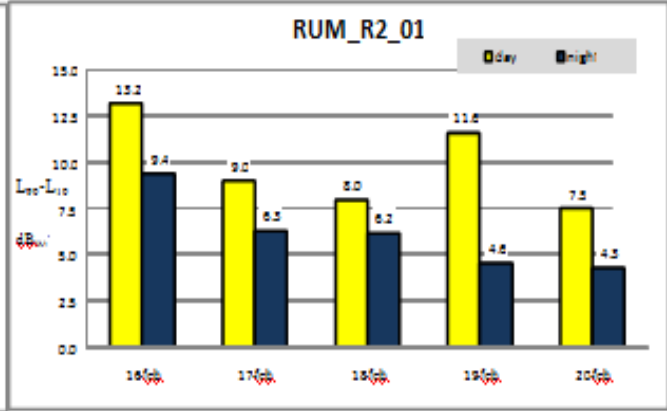

Figure 3. Difference between $\mathrm{L}_{10}$ and $\mathrm{L}_{90}$

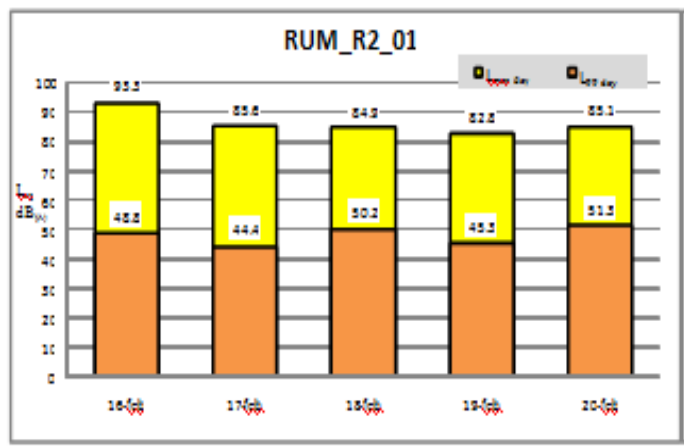

Figure 4. Levels $\mathrm{L}_{99}$ max., and and min. in the daily

\subsection{Summary of results}

The summary of the results of the measures in terms of the equivalent continuous noise in reference period daytime $\mathrm{L}_{\text {eq,d }}(6-22)$ and night period $\mathrm{L}_{\text {eq,n }}(22-6)$, is reported in Tab.4. The results show the existence of a field of the noise levels daytime, between 56.8 and $63 \mathrm{~dB}_{\mathrm{A}}$, and between 54.4 and $60.8 \mathrm{~dB}_{\mathrm{A}}$ in the night period. Is emerged that only four values have exceeded the maximum limit fixed for the night period of $0.8 \mathrm{~dB}_{\mathrm{A}}$.

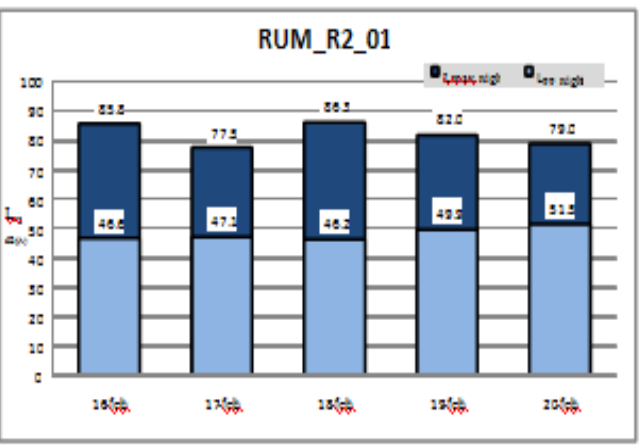

Figure 5. Maximum and minimum levels, L99 in the night

We can therefore say, that are not present misalignments substantial compared to the input levels, of the municipal acoustic classification and of the vulnerability of the urban land. The Tab. 4 reports the weighted equivalent levels measured at the station RUM-R2-01, R2-02 and R2-03.

The infrastructure sources hypothesized as concomitants with the railway line, are:

- A road urban (D), at separated carriageway;

- Two roads Urban of neighborhood (type E);

- A local road (type F) 
- A railway line.

The measurement stations for monitoring have been chosen so as to ensure the correct acquisition of the data and for characterize the sound field investigated, this in order to calibrate the model for the acoustic simulation within the bands of relevance. Account was taken of the main direction of origin of the noise, and of the presence of any obstacles and of the presence of sources concomitant noise.

The method used are been the monitoring R2: "noise measurements road of 24-48 hours with terminal semi-fixed".

The measurements were carried out in the external environment with continuous reliefs of 120 hours.

Purpose of this method is the determination of the $\mathrm{L}_{\text {Aeq }}$, the time reference of the daytime period $(\mathrm{TR}=6-22)$ and night period $(\mathrm{TR}=6.22)$.

In the Fig. 1 are identified the 3 major measure points inside, (R2-01, R2-02 and R2-03) of the railways station.

We note how the values in the daytime period are lower than $70 \mathrm{~dB}_{\mathrm{A}}$, and during the night period of $60 \mathrm{~dB}_{\mathrm{A}}$. In the Fig. 2 are shown the equivalent levels weighted.

The Fig. 3 shows the difference between the values of $L_{10}$ and $\mathrm{L}_{90}$, which gives us an indication of the dynamic of the levels measured. The measures show a dynamic not very variable in both reporting periods; this is due to the presence of noise somewhat stationary during period daily and night period. In the Fig. 4 and Fig. 5 are shown the maximum and minimum levels evaluated as percentiles $L_{99}$ respectively in the day and night periods.

The maximum levels are present almost always more by day, the values minimum levels instead are comparable during the two periods.

\section{MEASUREMENTS OF RAILWAY NOISE}

In the evaluation of the noise in the vicinity of a railway yard, the presence of several noise sources, must necessarily be taken into consideration.

The monitoring of the contemporary noise sources, related to rail traffic is aimed at the acquisition of extensive information for the assessment of noise emissions transit of freight and passenger trains.

In the present study, measurements were performed in the period between 18 and 19 February 2013.

In the Fig. 6 are shown the characteristics of the monitoring point and related information.

The values of the measures detected in the station are shown in the card of Fig. 6 and in Table 5:

Table 5 shows the summary of the results of the measures in terms $\mathrm{L}_{\mathrm{eq}}$, of the equivalent continuous noise and sound exposure level (or for event) $\mathrm{L}_{\mathrm{AE}}$.

- Name measure station, type of convoy, instrumentation adopted names of competent technicians, date, start and end time and total duration of the measure, sound level equivalent continuous, A-weighted sound pressure, the maximum level with fast time constants $\left(\mathrm{L}_{\mathrm{AFmax}}\right)$, sound exposure level (or level of the individual event) $\mathrm{L}_{\mathrm{AE}}$, photographic documentation of the source and of the context in which the measure is carried out, planimetric position of the point of measure;

- For each measure, information on the location and parameters of measure, analysis of the cumulative noise levels, percentile levels (L1, L5, $\left.\mathrm{L}_{10}, \mathrm{~L}_{50}, \mathrm{~L}_{90}, \mathrm{~L} 95, \mathrm{~L} 99\right)$, third of octave spectrum, table with values the equivalent level.

Table 5. Summary of the results

\begin{tabular}{|c|c|c|c|c|c|c|}
\hline Description source & $\begin{array}{l}\text { Height } \\
\text { microphone } \\
\text { [m] }\end{array}$ & $\begin{array}{l}\text { Distance } \\
{[\mathrm{m}]}\end{array}$ & $\begin{array}{l}\text { Duration } \\
\text { [s] }\end{array}$ & $\begin{array}{l}\mathrm{Leq}_{\mathrm{eq}} \\
\mathrm{dB}_{(\mathrm{A})}\end{array}$ & $\begin{array}{l}\mathrm{L}_{\mathrm{AE}} \\
\mathrm{dB}_{(\mathrm{A})}\end{array}$ & $\begin{array}{l}\mathrm{L}_{F \max } \\
\mathrm{dB}_{(\mathrm{A})}\end{array}$ \\
\hline Passenger train transit 1 & \multirow{24}{*}{1.5} & \multirow{24}{*}{7} & 0.00 .46 & 75.3 & 92,0 & 86.4 \\
\hline Passenger train transit 2 & & & 0.00 .20 & 78.7 & 91.7 & 82.6 \\
\hline Passenger train transit 3 & & & 0.00 .24 & 80.7 & 94.5 & 86.9 \\
\hline Freight train transit 4 & & & 0.01 .03 & 85.2 & 103.2 & 89.8 \\
\hline Freight train transit 5 & & & 0.00 .58 & 82.8 & 100.4 & 90.3 \\
\hline Passenger train transit 6 & & & 0.00 .40 & 78.7 & 94.7 & 87.2 \\
\hline Freight train transit 7 & & & 0.00 .45 & 89.9 & 106.5 & 94.0 \\
\hline Passenger train transit 8 & & & \begin{tabular}{|l|}
0.00 .21 \\
\end{tabular} & 78.9 & 92.1 & 85.5 \\
\hline Freight train transit 9 & & & 0.00 .31 & 74.5 & 89.4 & 79.3 \\
\hline Passenger train transit 10 & & & 0.00 .29 & 77.4 & 92.0 & 86.3 \\
\hline Freight train transit 11 & & & 0.00 .27 & 84.8 & 99.1 & 90.4 \\
\hline Passenger train transit 12 & & & \begin{tabular}{|l|l|}
0.00 .17 \\
\end{tabular} & 80.9 & 93.2 & 86.2 \\
\hline Passenger train transit 13 & & & 0.00 .18 & 80.9 & 93.5 & 86.9 \\
\hline Passenger train transit 14 & & & 0.00 .21 & 80.3 & 93.6 & 85.0 \\
\hline Passenger train transit 15 & & & 0.00 .21 & 80.9 & 94.1 & 87.6 \\
\hline Passenger train transit 16 & & & 0.00 .23 & 75.9 & 89.5 & 82.1 \\
\hline Freight train transit 17 & & & 0.00 .30 & 88.2 & 103.0 & 95.6 \\
\hline Passenger train transit 18 & & & \begin{tabular}{|l|}
0.00 .17 \\
\end{tabular} & 75.8 & 88.1 & 83.5 \\
\hline Passenger train transit 19 & & & 0.00 .23 & 74.3 & 87.9 & 79.1 \\
\hline Passenger train transit 20 & & & 0.00 .27 & 73.4 & 87.7 & 80.2 \\
\hline Passenger train transit 21 & & & 0.00 .26 & 75.4 & 89.5 & 81.6 \\
\hline Passenger train transit 22 & & & 0.00 .23 & 78.3 & 91.9 & 84.1 \\
\hline Freight train transit 23 & & & 0.00 .43 & 78.4 & 94.7 & 82.3 \\
\hline Freight train transit 24 & & & \begin{tabular}{|l|}
0.01 .12 \\
\end{tabular} & 78.2 & 96.8 & 86.6 \\
\hline
\end{tabular}




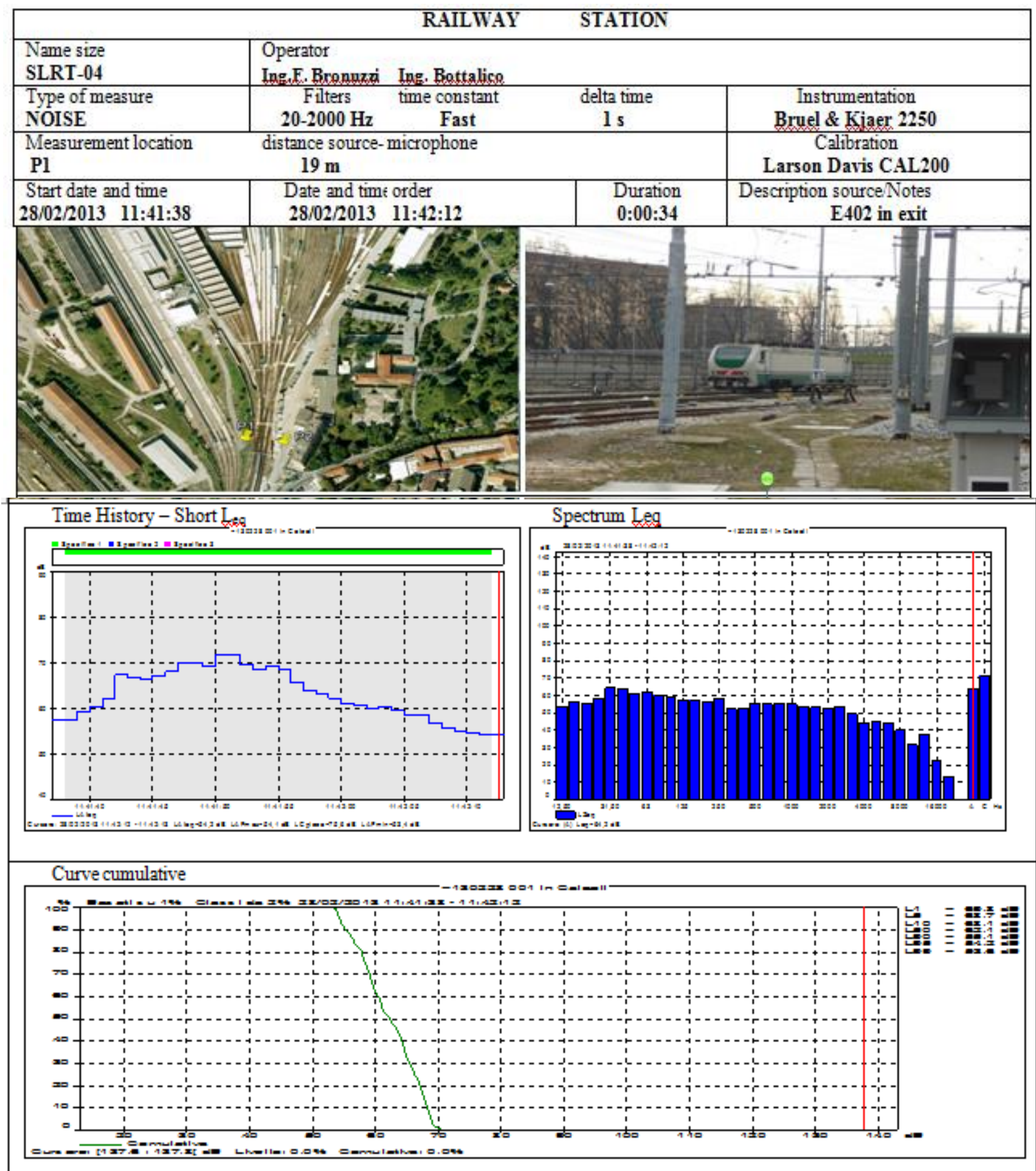

\begin{tabular}{|l|l|l|l|l|l|}
\hline \multicolumn{7}{|c|}{ Spectrum Leq } \\
\hline $\mathrm{Hz}$ & $\mathrm{dB}$ & $\mathrm{Hz}$ & $\mathrm{dB}$ & $\mathrm{Hz}$ & $\mathrm{dB}$ \\
\hline 12,5 & 53,6 & 160 & 57,0 & 2000 & 52,8 \\
\hline 16 & 56,5 & 200 & 56,4 & 2500 & 53,9 \\
\hline 20 & 55,3 & 250 & 58,6 & 3150 & 49,3 \\
\hline 25 & 58,0 & 315 & 52,5 & 4000 & 44,5 \\
\hline 31,5 & 64,6 & 400 & 53,0 & 5000 & 45,1 \\
\hline 40 & 64,2 & 500 & 55,4 & 6300 & 44,5 \\
\hline 50 & 61,4 & 630 & 55,0 & 8000 & 39,9 \\
\hline 63 & 62,4 & $\$ 00$ & 55,7 & 10000 & 31,7 \\
\hline 80 & 59,7 & 1000 & 54,9 & 12500 & 37,6 \\
\hline 100 & 58,8 & 1250 & 53,9 & 16000 & 22,9 \\
\hline 125 & 57,0 & 1600 & 53,4 & 20000 & 13,0 \\
\hline
\end{tabular}

Figure 6. Features of the monitoring point and measures 


\section{APPLICATION OF THE ACOUSTIC CHARACTERIZATION OF A RAILWAY STATION}

All values of the measurements can be used for the creation of a 3D numerical model.

Through which it is possible to calculate the acoustic impacts on individual receptors present in the study area, deriving from many noise sources, both internal ones and those eventually present in the station.

The simulation can be performed for reproducing, with the level of detail provided by the available maps, the geometry of the infrastructure, the distribution of current and future sources and their exercise patterns.

In they can be identified infrastructures that have the same geometric configuration with the study area, and can be defined the amplitudes of the respective bands of relevance. It can identified all the receptors that fall in the overlapping areas of the bands with those pertaining to railway infrastructure secondary.

These receptors must be occurred as indicated by 'App. 4 DMA 29/11/2000, for the correct definition of the regulatory limits. Where the limits imposed are exceeded, you must make the mitigation of noise with the installation of noise barriers, acoustic insulation sheds /absorbent, etc.

\section{CONCLUSIONS}

In this work we Evaluated the acoustic environment and the noise emissions in a railway yard, during operation.

Through the acquisition of information and data detailed, is possible make a project by mitigation of the sound sources, for reduce or eliminate the violations of the limits of law on the receptors exposed.

Were characterized the acoustic sources present at the station, and are been performed measurements of acoustic climate in the surrounding area the infrastructure.

With the characterization of the noise sources in the railway station, it was found a vast field of existence of noise levels between 53.2 and $89.3 \mathrm{~dB}_{\mathrm{A}}$, where the main noise sources are attributable to transit and stationing of the ETR500 and to the diesel locomotives D145 and D245.

From the measures of the acoustic climate it was found a field of existence of noise levels between 56.8 and $63 \mathrm{~dB}_{\mathrm{A}}$ in the daytime period, and between 54.4 and $60.8 \mathrm{~dB}_{\mathrm{A}}$ in the night period.

Were found only 4 exceedances (with maximum of 0.8 dBA) of regulatory limit valid for the night period.

We can therefore say that not there have been misalignments substantial respect at the immission levels to the municipal acoustic classification, and of vulnerability of urban land.

For the infrastructure of road transport, it has emerged the existence of a field of noise levels variable from 66.0-70.1 $\mathrm{dB}_{\mathrm{A}}$ during in the daytime period, and 57.0-66.5 dBA during the night period.

The only value that is within the limits imposed by the Presidential Decree 142/2004 is been the level measured for the daily period in one of the four stations, which is result less than $70 \mathrm{~dB}_{\mathrm{A}}$.

For transport infrastructure railway the level measured during the contemporary passage of trains passengers is been of $78.3 \mathrm{~dB}_{\mathrm{A}}$, while for freight trains of $82.8 \mathrm{~dB}_{\mathrm{A}}$.

The average duration of the transit of passenger trains is been $25 \mathrm{~s}$, and for freight trains of $46 \mathrm{~s}$.
The results of the investigations carried out in this work, supplemented by the data collected by the monitoring systems, installed on the urban transport vehicles [24, 25] will be of considerable help to the acoustic simulation of the area, so as to identify possible noises and predict actions and intervention for reduce them.

\section{REFERENCES}

[1] R. K. Mishra, M. Parida and S. Rangnekar, "Evaluation and analysis of traffic volume noise along has rapid transit system corridor," Int. Journal of Environ. Science Tech., vol. 1, pp. 737-750, Sept. 2010.

[2] Anisa B. Khan, "Impact of noise pollution on community health - A study at Pondicherry," Indian Association of Biomedical Scientists, vol.18, no. 3, pp. 183-190, 1998.

[3] T. VidyaSagar and G. NageswaraRao, "Noise pollution levels in Visakhapatnum City (India)," Journal of Environ. Science and Engg., vol. 48, no. 2, pp. 139-142, April 2006.

[4] C. C. Bhattacharya, Dr. S. S. Jain, S. P. Sing, Dr. M. Parida and Ms. Namita Mittal, "Development of comprehensive highway noise model for India condition" Indian Road Congress Journal, Paper No. 481, pp. 453-488, 2001.

[5] M. N. Rao and H.V.N. Rao, Air Pollution Control, Tata McGrawHill. 5. Peavy2008.

[6] H. M. E. Miedema and H. Vos, "Exposure-response relationships for transportation noise," Journal of the Acoustical Society of America, vol. 104, issue 6, pp. 3432-3445, 1998.

[7] J. Lambert, P. Champelovier and I. Vernet, Railway Annoyance in Europe: An Overview, Euro-Noise 98, Munchen, 1998.

[8] H. A. Nijland, S. Hartemink, I. Kamp and B. Wee, "The influence of sensitivity for road traffic noise on residential location: Does it trigger a process of spatial selection?" J. Acoust. Soc Am, vol. 122, pp. 1595-601, 2007.

[9] J. K. Ryu and J. Y. Jeon, "Influence of noise sensitivity on annoyance of indoor and outdoor noises in residential buildings," Applied Acoustics, vol. 72, pp. 336-340, 2011.

[10] G. Cannistraro, A. Piccolo, D. Plutino, A. Piccolo, "Evaluation and analysis of the environmental noise of Messina". Applied Acoustics., vol. 66, no. 4, pp.447465, 2005.

[11] A. Farina, "RAMSETE - a new Pyramid Tracer for medium and large scale acoustic problems," Proc. of EURO-NOISE 95 Conference, Lyon 21-23 March 1995.

[12] A. Farina, "Pyramid Tracing vs. Ray Tracing for the simulation of sound propagation in large rooms" volume "Computational acoustics and its environmental applications", pp. 109-116, Editor C.A. Brebbia, Computational Mechanics Publications, Southampton (GB), 1995.

[13] A. Farina, "Verification of the accuracy of the Pyramid Tracing algorithm by comparison with experimental measurements by objective parameters," ICA95 (International Conference on Acoustics), Trondheim (Norway), 26-30 June 1995. 
[14] G. Cannistraro, M. Cannistraro and R. Restivo, "Some observations on the radiative exchanges influence on thermal comfort in rectangular open-space environments," International Journal of Heat \& Technology, vol. 33, no. 79-84, 2015. DOI: 10.18280/ijht.330213.

[15] G. Cannistraro, M. Cannistraro and R. Restivo, "The local media radiant temperature for the calculation of comfort in areas characterized by radiant surfaces," International Journal of Heat \& Technology, vol. 33, pp. 115-122, 2015. DOI: 10.18280/ijht.330116.

[16] M. Cannistraro, G. Cannistraro, A. Piccolo and R. Restivo, "Potential and limits of oxidative photocatalyses and possible applications in the field of cultural heritage" "Advanced Materials Research, vol. 787, pp. 111-117, 2013, Trans Tech Publications, Switzerland.

[17] G. Cannistraro, M. Cannistraro, A. Cannistraro, A. Galvagno and G. Trovato, "Evaluation of the convenience of a citizen service district heating for residential use. A new scenario introduced by high efficiency energy system," International Journal of Heat \& Technology, vol. 33, no. 4, pp.167, 172, 2015. DOI: $10.18280 /$ ijht.330421.

[18] G. Cannistraro, M. Cannistraro and R. Restivo, "Messina's historical buildings after the earthquake of 1908: energy and environmental analysis through a global screening methodology," International Journal of Heat \& Technology, vol. 31, no. 2, 2013, pp.155, 158. DOI: $10.18280 /$ ijht.310221.
[19] M. Cannistraro, S. G. Leonardi, D. Aloisio, E Patti, C. Pace, W. Khalaf, N. Donato and G. Neri: "Development of Electronic-nose technologies for biomedical applications," XVII Annual Conference AISEM, Brescia Feb.5-7 2013.

[20] Department of Planning and Infrastructure, The Perth Urban Rail Development Office, "Perth urban rail development project-Suppl. master plan," Perth, Western Australia, 2002.

[21] European Commission, Environmental noise directive 2002/49/EG, 2002.

[22] G. Cannistraro, M. Cannistraro, A. Galvagno and G. Trovato, "Reduced of demand of energy cooling in the CED, Centers of Processing Data, with use of FreeCooling Systems," International Journal of Heat \& Technology, vol. 34, no. 3, pp. 408,502, 2016. DOI: 10.18280/ijht.340321.

[23] G. Cannistraro, M. Cannistraro, A. Galvagno and G. Trovato, "Technical and economic evaluations about the Integration of co-trigeneration systems in the dairy industry", International Journal of Heat \& Technology, vol. 34, Special Issue 2, October 2016.

[24] G. Cannistraro and M. Cannistraro, "Hypothermia risk, monitoring and environment control in operating rooms," International Journal of Heat \& Technology, vol.34, no. 2, June 2016, pp.165, 171. DOI: 10.18280/ijht.340202.

[25] G. Cannistraro, A. Cannistraro, M. Cannistraro and A. Galvagno, "Analysis of air pollution in the urban center of four cities Sicilian," vol. 34, Special Issue 2, Oct. 2016. 